\title{
Discussion on the Effect of Creative Industry on the Teaching Model of Clothing Design
}

\author{
Tian Lan \\ Changchun University of Technology \\ Changchun, Jilin, China 130000 \\ Shih Chien University \\ Chinese Taipei 10462
}

\begin{abstract}
Our country has begun to vigorously develop the creative industry since the GDP leaped to the second in the world in 2010. The clothing industry is important in the creative industry. We shoulder heavy responsibilities in the development of clothing specialty. Under this background, it is necessary to find new ways and methods for the clothing specialty to strengthen the cooperation between school and enterprise and improve the quality of applied talents.
\end{abstract}

Keywords-creative industry; clothing design; development pattern

\section{INTRODUCTION}

The creative industry is also known as the cultural creative industry (hereinafter referred to as the creative industry). As a burgeoning force, it has been developing rapidly in all directions, becoming one of the important industries in promoting the economic development of our country. With the ceaseless development and renewal of science and technology, all industries including the creative industry of our country at present are developing fast. The development of advanced and digital technology provides many supportive measures to ensure the smooth development of creative industry. However, because nowadays the market competition becomes increasingly fierce, the innovation ability development is impeded. For example, the innovation ability development of the clothing industry in our country is impeded because of the influence of the homogeneous products in the flow production line.

\section{ThE DEVElopment StATUS OF CREATIVE INDUSTRY IN OUR COUNTRY}

In the creative industry, people pay attention to the originality of clothing. The creative designers make a figure in the fashion field under the background of cultural industry. However, compared with the same type of brands in the western countries, the brands in our country are still in the initial stage. There are many reasons, including fail to get the support of the government and the industry for a long time and lack funds and profound cultural deposits as well as experience in operation. We have a long way to go in developing the clothing specialty under the background of creative industry. In order to get better development opportunities, costume designers should have the courage to bring forth new ideas, build professional teams and participate in the international competitions frequently to improve their popularity.

At present, the comprehensive national strength of China has developed and grown gradually, accompanying with the obvious improvement of cultural soft power. The creative industry is developing rapidly. Western developed countries as well as Japan and South Korea in Asia first develop the creative industry. Supportive policies are introduced by these countries to lay a solid foundation for the development of creative industry. The most typical is the economic giant America, occupying an important position in the national cultural industry. It has become the superpower because of the powerful economic strength. America has been in the cuttingedge of the creative industry development, gradually forming a powerful cultural tide, exporting and dumping cultural products to the countries all over the world. Because of a late start and slow development in the cultural industry, great gaps still exist between the countries like America and South Korea and our country. For example, taking the eastern region of our country as an example, its geographic location provides advantaged conditions for the development of creative industry. The application of network advanced technology and innovation ability and cultural exchange are in continuous development; because it has rich experience in the innovation, development and promotion of the creative industry, it can develop fast and play a leading role in the development of creative industry of our country. Moreover, it can participate in the competition and make a difference with its strengths in the increasingly fierce market of international creative industry. Many young costume designers have made a figure fast with the help of advantaged geographical location in the eastern region.

\section{The DeVElopment Status AND PROBlems FACED By THE ClOThING SPECIALTy OF OUR COUNTRY}

\section{A. The Development Status of Clothing Specialty of Our Country}

The fashion week is an annual event of the fashion world. There is no lack of Chinese designers of the clothing specialty in the fashion week held in Paris and Italy. Most of them have the background of studying abroad. Therefore, it is not difficult 
for the designers of clothing specialty in our country at present to attend the overseas fashion week like ten years ago.

\section{B. Problems Faced by the Clothing Specialty of Our Country}

Firstly, lack of available resources. The products designed by designers just graduated from universities should be chosen by the masses. There are many limitations such as the selection of clothing fabrics. In the international market, the update of shell fabric is free-running and different shell fabrics have different prices. Good shell fabric is particularly important to design good products. Designers just graduated cannot choose good shell fabrics because of no financial support; furthermore, some shell fabrics are sold in the international market instead of the domestic market. More time and higher cost will be spent in purchasing it from abroad. Therefore, the primary task of the clothing specialty in our country is to solve the problem of resource starvation.

Secondly, lack regular customers. Products designed by designers will be sold at length. The market is very important for the brands. However, at present, after launching the products, most designers lack sufficient and stable customer resources.

Thirdly, the working capital of the studio is limited. Designers have to spend a lot in renting the studio and the equipment. In order to save money, most designers rent the design studio in the outskirts. Although it reduces the cost, the efficiency cost will increase greatly because of the problems in the distance and communication with customers.

\section{Suggestions to the DeVElopMent OF Clothing SPECIALTY ON THE BASIS OF CREATIVE INDUSTRY}

Nowadays, the creative economy has swept the globe. The internationalization process is accelerated increasingly. In order to grasp the culture creativity, the clothing professionals should break the traditional extensive pattern and the homogeneous development pattern to increase the effectiveness and reduce the cost.

\section{A. Develop the Network Marketing Platform}

The development of internet technology and the flourish of e-commerce platform have brought great opportunities for the clothing specialty. In the search interface of Taobao, input the keywords and then we can see many e-commerce sellers sell clothing on it. The number still increases continuously. Besides, the $\mathrm{B} 2 \mathrm{C}$ and $\mathrm{B} 2 \mathrm{~B}$ commercial platforms are also booming. The platforms above are customized for designers, including online and offline platforms. The online e-commerce marketing and the offline marketing in the physical stores have provided good opportunities for some small design studios and let more people know about the name and brand of Chinese designers. The WeChat business develops rapidly even leads the trend in China fast. Network marketing can be carried out through the WeChat friend circle and the weibo. The emergence of the WeChat business brings valuable business opportunities for the clothing specialty.

\section{B. The Participation of Professional Organization Team}

Professional organization team of design can attend the fashion week through the select shop. It enables many designers to recommend themselves as well as market their designs. It is the best way for designers without much experience to improve the popularity and market the design of them.

\section{Participate in the International Competitions}

Participating in the international competitions of clothing, designers can exchange with excellent designers to produce more culture creativity, and continuously improve their abilities through comparing the strengths and weaknesses; meanwhile, they can market the design philosophy and improve the popularity. Undoubtedly, it is very helpful to participate in more international competitions.

\section{National Policy Support}

The development of creative industry cannot do without the support of international policies and the industry. In recent years, a series of policies have been introduced in our country to support the development of the cultural industry, such as reduce the rent of studio, and build the platform for designers to exchange the culture creativity and provide professional guidance and help for designers.

\section{E. Strengthen the Development of Culture Creativity Area}

The creative industry has the meaning of "culture creativity". Therefore, in order to strengthen the development of culture creativity, we should at first pay attention to the development of culture creativity and provide a good development space.

\section{CONCLUSION}

With the rapid growth of economy in our country, people's living standard has improved greatly. They improve the aesthetics for clothing and pay attention to the creative design continuously. However, because the creative industry in our country starts late, great gaps still exist between other developed countries and ours. In order to bridge the gap, it is necessary to change from the thought of "Made in China" to that of "Create in China". The talents of clothing design must improve their quality, accelerate the vertical and horizontal integration and improve the industry chain to the strategic production mode of win-win cooperation, and then create a sound and efficient clothing industry. Furthermore, provide a more reasonable market development mechanism and promote the development of culture creativity of the clothing specialty in our country through the training, employment, professional knowledge and basic skills as well as the way of learning by doing.

\section{REFERENCES}

[1] Liu Jing. Research on the Current Situation and Development of the Education in the Fashion Show Specialty of Chinese Universities [D], Suzhou University, 2014 
[2] Chen Jiayu. Research on the Current Situation of Brands of Independent Fashion Designers under the Environment of Creative Industry Growth [J], Art Science and Technology, 2015, (02)

[3] Hu Ling. Research on the Development Countermeasure of Clothing Industrial Cluster on the Basis of Circular Economy [J], Productivity Research, 2015, (04)

[4] Zhong Qusheng. The Professional Development of Illustration in Chinese Cultural Creative Industry [D], Chinese National Academy of Arts, 2011

[5] Tian Qingfen. The Development of Creative Industry of Taiwan and Its Extension to the Mainland [D], Nankai University, 2013

[6] Wang Ying. Research on the Financing Pattern of Asset Securitization in the Cultural Creative Industry [D], Beijing Institute of Technology, 2014. 